Volume 1, Number 2, Juni 2020

Journal of Research on Mathematics Instruction

Link jurnal: http://jrmi.ejournal.unri.ac.id

\title{
The Mathematical Instructional Model in Fostering Critical Thinking
}

\author{
Buhaerah ${ }^{1}$, Siri Dangnga 2 \\ 1 State Islamic Institut of Parepare, INDONESIA \\ 2 Muhammadiyah University of Parepare,INDONESIA \\ ARTICLE'S \\ INFORMATION \\ Article history: \\ Received: Dec-08-2020 \\ Accepted: Dec-26-2020

\begin{tabular}{lr}
\hline Keywords: & Model, \\
Mathematics, & Learning, \\
Critical, Thinking &
\end{tabular} \\ ABSTRACT \\ The main issues raised in this research was" how the process and results of the \\ development of mathematical learning model that develops critical thinking skills in \\ brief development mathematical instruction model in fostering critical thinking, \\ colled MICT. The model developed new MICT until the test phase was limited, \\ therefore to determine its effectiveness on a broader scope. Aspects of students' \\ critical thinking applied in this model can be modified by teachers who are \\ interested in implementing this model, modification can be done by adjusting the \\ environment and culture of the students.

\section{Corresponding address:} \\ Buhaerah, \\ E-mail: buhaerahstain@gmail.com
}

\section{INTRODUCTION}

A critical thinking ability defined as one of the aims in Mathematical instruction [1]. Today, a critical thinking ability is needed by students to raise their quality of thinking result and original of intellectual thinking [2] [3]. The government also decided of teaching organizer to supply students' critical thinking ability as their next competence. Clarified critical thinking as known as soul activity to appreciate the truth of the argument, to submit questions, as well as to evaluate [4]. According to stated critical thinking is to interpret, to evaluate the result of observation, to communicate and to declare.

Be related to critical thinking ability as Mathematical teaching goal, it is still distant from reality [5][6]. It is seen of some introductions of research that indicate critical thinking is still distant from the expectation, they are: most or $80 \%$ of them have not known the steps to get the answers with the data and the support evidence, and the reasons how to get them [7]. Besides, students experience troubles to determine the correct or wrong value of an argument and to give an explanation with their reasons [8]. One of the causes is less of the information that is known by students to arrange arguments and to communicate.

Be related to critical thinking as mathematical teaching goal, some researchers reported that to develop critical thinking ability is less to get attention from teacher even students. stated that most of the teachers in their teaching practices served the material, and gave some examples to students [9] [10]. The process to construct the material is less to be successful, and there will be the tendency of students to be guided or given the instruction of problem-solving completely [11]. Declared that most of the students did not get the purpose of the completion process [12]. So, students have not mastered the knowledge that should be had to think critically. 
Teaching process that supports critical thinking ability development could be done with teaching the students to make and to arrange the argument, especially in problem-solving activities, intellectual development, individual working, and group working [13] [14]. Other activities that support critical thinking ability development, these are: justifying the information, identifying the concept, as well as supplying the support evidence.

The purpose argument in thinking critically is an argument which is supported by evidence and relevant data with the problem and is arranged logically, so its truth could be trusted and be convinced. Be following [15] that a good argument is arranged with complete consideration, fill expediency criteria, should be with support reasons and contains a solution of the problems. Stated that algorithm which is completed with argument or reason of way to get the answer is easier to know [16]. So, learning to arrange and to inspect the argument will allow thinking critically [17].

Be related to arrange and to make argument clarified that teachers should have habituated their students to identify and to justify information with making logical and systematic reasons. Therefore, the vacillations which hamper someone to increase on the next level are easier to solve. Meanwhile, [18] stated that making and arranging an argument to build knowledge will influence someone's skill to solve the problems. Clarified that problem solver which is supported with relevant evidence will let someone have critical thinking skill [19]. Therefore, needing some efforts to make students' potential of learning for making and arranging the argument, and increasing teachers' complicity in providing material [20].

Some researchers have developed a teaching model which develops critical thinking skill. Designed teaching model or teaching pattern with creating compatible teaching condition, such as; building communication in expressing ideas, indicating the passion of the ideas, working as a grouping to achieve the goal [21]. Designed teaching model which combines with the attitude, knowledge, and skill to recognize the problem and to find out supporting evidence [22]. Knowledge is related to generalization, abstraction process, and drawing the valid conclusion [23]. Meanwhile, skill is related to apply the attitude and knowledge. [18] Developed a teaching model with ABC. $\mathrm{ABC}$ is an acronym of Anticipation, Building knowledge, and consolidation. ABC model is to assign students to do research, to solve the problem, to work cooperatively, and to reveal oral ideas that get of the writing.

Based on the teaching model, students' roles in teaching model to make and to arrange the argument are not explicit in every single teaching step [24] [25]. Therefore, a new teaching model is needed, to make and to arrange an argument to develop critical teaching skill.

Students must learn to make and to arrange the argument to develop critical thinking skill, these are: to make someone easier in discuss, to inspect the information of some sources, to ask the correctness value, and to address solution [26]. To make someone easier to communicate the evidence, and supporting data and the explanation of how to get the answer [27]. Students can assess the truth and to ask the solution, to find out a new idea and another idea, to know and to comprehend the relating concept, and to change opinion in explaining the concept mutually [28].

The explanation of introduction research result and the results of research indicates that Mathematica teaching has been the main target in teaching, they are concept, fact, and operation. Then, other objects such as, problem-solving, learning transfer, Individual working, and group working are reputed as the impact of learning, so it is interesting to inspect deepen politicly or empirically in Mathematical learning model that develops critical thinking skill called MICT model.

Stated that a teaching/learning model is a generalized instructional process which may be used for many different in a variety of subjects. [29] stated that learning model is an instruction 
for a teacher in planning the learning, preparing the learning set, choosing media, and implementing evaluation that direct of goal accomplishment effort [30] [31]. The meaning of the opinion is learning model suits in every subject and has a purpose to help the teacher to do learning activities [32]. Then, suggested that there are four important components of a learning model, they are the syntax, social system, reaction principle, and supporting system. The explanations of each component are:

1. Syntax

The inspection result of some learning theory, critical thinking theory, and learning models [33]-[36]. MICT model syntax that is successful to be designed from four phases. Phase one: To identify and to justify concept, phase two: to solve the problem, phase three: generalization and to analyses algorithm and phase four: conclusion. For more information, see the below table:

Table 1. Syntax MICT Model

\begin{tabular}{|c|c|c|}
\hline Syntax Model & Teacher Activity & Students Activity \\
\hline $\begin{array}{l}1^{\text {st }} \text { phase: } \\
\text { Identify and justify the } \\
\text { concept }\end{array}$ & $\begin{array}{l}\text { 1. The teacher divides the student into } \\
\text { small groups. } \\
\text { 2. Assigning the students to read the } \\
\text { material or the activity, and determine } \\
\text { the concepts that are connecting with the } \\
\text { main problem. } \\
\text { 3. Assigning the students to arrange the } \\
\text { relevant argument for explaining the } \\
\text { concept. } \\
\text { 4. Choosing the students by turns to } \\
\text { explain the concept, and give a question } \\
\text { about the unclear material. }\end{array}$ & $\begin{array}{l}\text { 1. Every student joins the groups. } \\
\text { 2. Read and understand the materials } \\
\text { or the activities, and determine the } \\
\text { concepts that are connecting with } \\
\text { the main problem. } \\
\text { 3. Make an argument with supporting } \\
\text { reason. } \\
\text { 4. Shorting the concept in teaching } \\
\text { materials, and asking for the unclear } \\
\text { materials. }\end{array}$ \\
\hline $\begin{array}{l}2^{\text {nd }} \text { phase: } \\
\text { Solve the problem }\end{array}$ & $\begin{array}{l}\text { 1. Assigning the student in groups to solve } \\
\text { the problem on the paper. } \\
\text { 2. Assigning the student in every group to } \\
\text { evaluate the answer. } \\
\text { 3. Asking the informant on give feedback } \\
\text { of the question. }\end{array}$ & $\begin{array}{l}\text { 1. Give respond to the teacher's } \\
\text { command by determining } \\
\text { (understand and question), making } \\
\text { math model and the solution. } \\
\text { 2. Giving suggestion/comment, and } \\
\text { evaluate the answer. } \\
\text { 3. Choosing one answer then give it to } \\
\text { the teacher. }\end{array}$ \\
\hline $\begin{array}{l}3^{\text {rd }} \text { phase: } \\
\text { Generalize and analyze } \\
\text { the algorithm. }\end{array}$ & $\begin{array}{l}\text { 1. Assigning the student to make a } \\
\text { presentation in the class. } \\
\text { 2. Allows the students or other groups to } \\
\text { give an idea or question. } \\
\text { 3. Directing the informant to give a good } \\
\text { answer to the question. }\end{array}$ & $\begin{array}{l}\text { 1. Making a presentation in the class } \\
\text { (just the selected group). } \\
\text { 2. Checking, comparing the answer, } \\
\text { appreciate and asking the value. } \\
\text { 3. Giving feedback by completing the } \\
\text { supporting data, and giving an } \\
\text { explanation with the way to get the } \\
\text { answer. } \\
\text { 4. Revising the wrong answer. }\end{array}$ \\
\hline $\begin{array}{l}4^{\text {th }} \text { phase: } \\
\text { Conclusion }\end{array}$ & Assignin & $\begin{array}{l}\text { Concluding the material that has been } \\
\text { learned }\end{array}$ \\
\hline
\end{tabular}

\section{Social system}

MICT model Social system followed relation pattern which is equilibrated between teachers and student or student with the student [37]-[39]. The relation is seen in every steps MICT model. In phase one, a student could be construction the concepts, facts, operations, and principles which are formed in some activities as an effort to know and to comprehend mathematics' material. Phase II, students cooperate in finishing the exercises with identifying the problem (known, and asked), making the mathematic model, and its arrangement. Phase III, students obtain a deep understanding of a problem with looking into/repairing finishing steps which have not been 
correct, furnishing supporting data which is still less, and giving explanation the way to get it from every procedures problem fissions. Phase IV, students make a material resume which is told by themselves, assessing and evaluating the process that has been done. Meanwhile, the teacher just gives some upgrading suggestions about the conclusion.

\section{Reaction principle}

The results of the study of several [40]-[42] research results about the concept of the principle of reaction, including: (1) giving an opportunity to students to be exploration, giving a chance to student to do prediction and hypotheses, trying another solution and discussing, (2) giving an opportunity to another student to serving and reflexing findings in front of the class, (3) giving directions to students to answer the problem on the exercise sheet, addressing arrangement steps, giving an explanation in every algorithm, observing and controlling the finishing. (4) Respecting all students' activities which support the learning process and giving directions students' activities which hamper the learning process.

\section{Supporting system}

Some supporting systems on the MICT model are learning set that consist of a learning plan, teaching material, students' activities sheet [43]-[45]. Learning plan consists of four are: (1) questions or teachers' duties, this component contains teachers' order or message to students. (2) students' responses or answers are expected, this component contains answer or response of teacher's order, (3) teacher's reaction of the students' answers, this component contains teachers' reaction of the students' answers are related to the questions which are addressed, and (4) teacher's note/reflection.

Teaching material is designed to invite students to know and to comprehend the concept in Mathematic, to serve finding's results, to use an algorithm, and to be generalization technical skill. Meanwhile, students' activities sheet which is designed specially to demand students to study Mathematic which is relevant to problems or tasks which are given. In this part, an activities sheet is prepared working column, as a place or answer column for students to write their results.

\section{METHODS}

Learning model will be developed to refer on the steps of model developing which is stated by Plomp [46], is: (a) identifying the problem an analyzing the necessary, (b) planning and implementation, and (c) evaluation. Meanwhile, the components which are covered in MICT model tend in Joice \& Weil's components of learning model: (a) syntax, (b) social system, (c) reaction principle, and (d) supporting system [29]. Then, quality criteria of the learning model which are developed of Nieeven is valid, practical, and effective [46]. In steps or procedure's implementation of MICT model developing research could be indicated on the picture.

\section{RESULTS AND DISCUSSION}

The result of the validation experiment and the tryout of MICT model shows that MICT model has been completing the criteria of validation. Practical and effective those results are got by the procedure of product development according to Plomp which has been modified by entering the model components according to Joyce \& Weil and the indicator of product quality by Nieeven [46] [29]. 
The result of this research and development strengthen the prior invention, one of that: Paul \& Elder by a title "using critical thinking to foster student learning and community engagement" [47]. Watson \& Glaser by the title "critical thinking appraisal" which develops the standard of critical thinking and the indicator of critical thinking [48]. Bajracharya by the title" teaching mathematics through the $\mathrm{ABC}$ model of critical thinking". $\mathrm{ABC}$ model is an acronym of anticipation, building knowledge, and consolidation [18]. By the title" improved critical thinking skills as a result of direct instructional and their relationship to academic achievement".

The main point of the four researchers above: (1) every learning needs to engage the objects that support someone to think critically and place it as the main purpose of learning. (2) the objects of mathematic learning are one of the tools to think critically. (3) social interaction and collaborative work can develop the ability to think critically. There is also a discussion about the result of the MICT development model in mathematic learning which is focused on the MICT model. That is: identify and justify the concept. The problem solves, algorithms analyze, generalize, and conclusion. The discussion of these are.

1. Identify and justify the concept

In the prior session has been explained that the indicator of the ability to think critically in the phase of identifying and justifying the concept is the student chooses and keep the main concept. Then give an explanation by their way by the right way as well. The gaining of this indicator is taken by reading and understanding the activities which are available in the book. Next, interpret and make an assumption. next, explain it to their friends.

Some factors support the development of thinking critically in the step of identifying and justifying the concept. They are: (1). A free chance for the students to explore and build their knowledge. (2) the parts of the book, guide the student to find the information with their way. Press out the students to a discussion. (3). Give a chance to students to present their material in front of their group mate.

This finding enriches the prior finding. Combinate reading understanding material, and also social interaction to think critically [49]. Then the findings of the author in this research is a bit specific that is looking for the information, then choose the important point, as well as explained by its own words. These findings have the same result with reveals that developing thinking critically in students can execute by giving enough time to build their understanding by reading and understanding the concept [18]. Also as the reflection of all items. Thus we can make a conclusion that Identifies and justify is an activity that can strengthen knowledge about cognitive sources and solve problem solution.

\section{Problem Solving}

Indicators of critical thinking skills in the phase of solving the problem are to identify the problem (note, asked, adequacy of elements) and create a mathematical model correctly, then the solution properly. In this phase, students are assigned to think to create a solution or an answer and create ideas, express opinions or ideas.

Also, students work collaboratively to solve problems. Working collaboratively is to do the job by combining a variety of different potentials to solve the problem. These findings enrich the findings Stacey stated that the participation of all students or colleagues in a group can help create solutions that truth can be trusted and believed [50]. Likewise, Gokhale stated that work collaboratively to improve learning outcomes, especially in terms of process and mastery of subject matter [51].

3. Algorithms analyze and generalize 
Indicators of critical thinking in the phase generalize and analyze algorithms there are two, namely: (1) the student is able to inspect, repair, and provides an explanation of each step algorithm solving the problem completely and correctly, and (2) the student is able to complete the supporting data, determine a general rule, and provides an explanation of how to get it completely and correctly.

Overview of critical thinking skills on the indicator 1, include: skilled students analyze various solutions or answers based on the flow or procedure that has been done before, and can contribute ideas, opinions or ideas. In this phase, analyzing algorithms are considered useful by most students, as a means to understand the work of self and others.

These findings are relevant to the results of previous studies, such as; Glaser stated that the application of the discussion, exploration, and investigation in the learning activities is an important activity for critical thinking [52]. Along with King \& Goodson states that develop critical thinking skills of students, teachers need to facilitate the students to do the analysis and self-reflection [53]. Activity analyzing algorithms that can integrate an understanding of the flow of students who have obtained the actions better, and strengthen the effectiveness of learning.

Picture of students' critical thinking skills in the second indicator, which can furnish the supporting data and determine a general rule, as well as explaining how to get it completely and correctly. Students skillfully linking of one concept to another, and to apply these concepts to the problems, and learning math more independent anytime and anywhere.

Some advantages of the generalization are: able to increase mathematics' material mastery, students are faster and easier to comprehend the material, to find out the relation among the concepts, and able to apply concepts which are comprehended in another field.

These research results enrich the previous findings, such as stated that to furnish the supporting data in every answer could raise the insight and mathematics' material mastery better [54]. Student response in explaining the way to get their answers, able to prompt their passion individually or group working.

Developing process of MICT model tends on product developing theory which is stated by consists of three phases: (a) Identifying problem and analyzing necessary phase, (b) planning and implementation phase, and (c) Evaluation phase. This research produces some education products that have filled valid criteria, practical, and effective. They are: (1) Mathematical learning model which develops critical thinking skill, (2) learning sets (learning plan, and teaching material) which are arranged according to MICT model, and (3) research instruments are related on developing the process.

The product teaching results that revising. MICT model syntax includes: identifying and justifying the concepts, solving the problem, generalization and analyzing algorithm and conclusion. The results that are getting with using the syntax in every trial:

1. Trials one

Results that are reached in trials one is MICT model that has filled practical and effective criteria. This is seen two indicators practicality have been reached, are: the implementation MICT model generally in the category fewer have not been implemented, and the students' activities that are expected have been completed. The complete indicator is teachers' skill in managing the learning process in a good category and the students' responses are positive. Then, the effectiveness indicator is a rating score of critical thinking skill in learning and test score of critical thinking skill in comprehending the material have not filled the effectiveness criteria.

2. Trials two 
Results that are reached in trial II is MICT model that has filled practical and effective criteria. This is seen one indicator practicality MICT model has been reached, are students' activities that are expected MICT model have not been filled. Meanwhile, another indicator that has been filled is the implementation MICT model generally in the category fewer have been implemented, teachers' skill in managing the learning process in a good category and the students' responses are positive. Then, the effectiveness indicator is a rating score of critical thinking skill in learning and test score of critical thinking skill in comprehending the material have not filled the effectiveness criteria.

3. Trial three

The result of the third trials is MICT models have been completely achieving the practical and effective's criteria. It shows by the indicators MICT practical's model that has been achieving, they are: (1) implementation of model components generally in the category that has worked well, (2) the expected of student activity of MICT model have been met, (3) the teacher's ability to manage the learning process is going well, and (4) positive respond from the students. As well as the effective indicator showing the score of the critical ability in the learning process and the score of critical thinking ability test in understanding the material has been met the criteria of effectiveness. Therefore, MITC models developed have valid, practical, as well as effective's criteria.

\section{CONCLUSIONS AND SUGGESTIONS}

Some of the finding that have contributed on the research that are: in the 1st and 2nd trials we can find some of the student's activity spends more time they are: (1) explaining concept and the math learning principals; (2) identified the questions (understanding, asking, adequacy element), making math models, and the answer, (3) checking, fixing, as well as giving explanation of the steps of solving algorithm's problem; (4) the student individually or group presenting their opinion/ idea in the class. As a consequence, the ideal time will not achieve. But, on the 3rd trials little by little will be getting well until all the acts are done.

Another finding that is contributed in this research, they are: (1) the seriousness and teacher's spirit to learn and understanding in detail the implementation's technique of MICT models, and (2) the willingness of the teacher to do a simulation in the different class before do the trial for the selected class.

Whereas suggestion for the research, are: (1) MICT models which are developed are still you and limited on 3 class, so to know the effectiveness for the wide-area, we suggested to implementing it in the schools. (2) The critical thinking aspects which are applied to the MICT model can be modified by the teachers, modifying of the MICT model should be suitable with the student's range and culture. Thus, the equipment of MICT models will be modified as well.

\section{REFERENCE}

[1] N. G. Holmes, C. E. Wieman, and D. A. Bonn, "Teaching critical thinking," Proc. Natl. Acad. Sci., vol. 112, no. 36, pp. 11199-11204, 2015.

[2] C. Saiz and S. F. Rivas, "New Teaching Techniques to Improve Critical Thinking. The Diaprove Methodology,” Educ. Res. Q., vol. 40, no. 1, pp. 3-36, 2016.

[3] G. Çavdar and S. Doe, "Learning through writing: Teaching critical thinking skills in writing assignments," PS - Polit. Sci. Polit., 2012.

[4] T. E. Ruggiero, "Uses and Gratifications Theory in the 21st Century," in Refining Milestone Mass Communications Theories for the 21st Century, 2018.

[5] D. Tall, "How Humans Learn to Think Mathematically," How Humans Learn to Tbink Math. 
Explor. Three Worlds Math., no. April, pp. 1-457, 2013.

[6] S. M. Blinder, "Mathematical Thinking," in Guide to Essential Math, 2013.

[7] M. Lloyd and N. Bahr, "Thinking Critically about Critical Thinking in Higher Education," Int. J. Scholarsh. Teach. Learn., vol. 4, no. 2, pp. 1-16, 2010.

[8] T. D.-B. R. Collective, "Design-Based Research : An Emerging Paradigm for Educational Inquiry," Educ. Res., vol. 32, no. 1, pp. 5-8, 2011.

[9] K. R. Burton, J. J. Mellema, M. E. Menendez, D. Ring, and N. C. Chen, "The yield of subsequent radiographs during nonoperative treatment of radial head and neck fractures," $J$. Shoulder Elb. Surg., 2016.

[10] R. H. Ennis, "Is Critical Thinking Culturally Biased?," Teach. Philos., 2012.

[11] J. L. Krawec, "Problem Representation and Mathematical Problem Solving of Students of Varying Math Ability," J. Learn. Disabil., 2014.

[12] S. Mystakidis, E. Berki, J. Valtanen, and E. Amanatides, "Towards a blended strategy for quality distance education lifelong learning courses: The patras model," in Proceedings of the European Conference on e-Learning, ECEL, 2018.

[13] H. Innabi, "Aspects of critical thinking in classroom instruction of secondary school mathematics teachers in Jordan," in The Mathematics Education into the 21st Century Project Proceedings of the International Conference, 2003, pp. 124-129.

[14] K. Kurniati, Y. S. Kusumah, J. Sabandar, and T. Herman, "Mathematical Critical Thinking Ability through Contextual Teaching and Learning Approach," Indones. Math. Soc. J. Math. Educ., vol. 6, no. 1, pp. 53-62, 2015.

[15] M. I. Cicchino, "Using Game-Based Learning to Foster Critical Thinking in Student Discourse," Interdiscip. J. Probl. Learn., vol. 9, no. 2, 2015.

[16] H. Sahamid, "Fostering Critical Thinking in the Classroom," Adv. Lang. Lit. Stud., vol. 5, no. 6, pp. 166-172, 2014.

[17] M. Forster, "Higher Order Thinking Skills," Res. Dev., vol. 11, pp. 1-5, 2004.

[18] A. Bajracharya, "Knowledge, attitude and practice of contraception among postpartum women attending Kathmandu Medical College Teaching Hospital," Kathmandu Univ. Med. J., 2016.

[19] E. Berki, J. Valtanen, S. Chaudhary, and L. Li, "The need for multi-disciplinary approaches and multi-level knowledge for cybersecurity professionals," in Multidisciplinary Perspectives on Human Capital and Information Technology Professionals, 2018.

[20] S. R. Mehta and R. Al-Mahrooqi, "Can thinking be taught? Linking critical thinking and writing in an EFL context," RELC J., 2015.

[21] M. Mărcuț and M. Mărcuț, "Single Market and the Digital Single Market," in Crystalizing the EU Digital Policy, 2017.

[22] L. Magnussen, D. Ishida, and J. Itano, "The Impact of the Use of Inquiry-Based Learning as a Teaching Methodology on the Development of Critical Thinking," J. Nurs. Educ., 2018.

[23] D. K. Simonton, "Creative problem solving as sequential BVSR: Exploration (total ignorance) versus elimination (informed guess)," Think. Ski. Creat., vol. 8, no. 1, pp. 1-10, 2013.

[24] L. Sternod and B. French, "Test Review: Watson-Glaser II Critical Thinking Appraisal," J. Psychoeduc. Assess., vol. 34, no. 6, pp. 607-611, 2016.

[25] T. A. Walkowiak, H. H. Pinter, and R. Q. Berry, "A Reconceptualized Framework for 'Opportunity to Learn' in School Mathematics," J. Math. Educ. Teach. Coll., vol. 8, no. 1, pp. 7-18, 2017.

[26] B. Reys, Robert; Rogers, Anna; Bennett, Sue; Cooke, Audrey: Robson, Kylie: Ewing, Helping Cbildren Learn Mathematics. 2017.

[27] X. Wang and H. Zheng, "Reasoning Critical Thinking: Is It Born or Made?," Theory Pract. Lang. Stud., vol. 6, no. 6, p. 1323, 2016.

[28] J. Maynes, "Thinking about Critical Thinking," Teach. Philos., vol. 36, no. 4, pp. 337-351, 
2013.

[29] B. . Joyce, M. Weil, and E. Calhoun, Models of Teaching. 2011.

[30] C. Y. Lin and S. Cho, "Predicting creative problem-solving in math from a dynamic system model of creative problem solving ability," Creat. Res. J., 2011.

[31] M. S. Mkhabela, R. Gordon, D. Burton, A. Madani, and W. Hart, "Effect of lime, dicyandiamide and soil water content on ammonia and nitrous oxide emissions following application of liquid hog manure to a marshland soil," Plant Soil, 2006.

[32] S. Chaudhary, E. Berki, L. Li, and J. Valtanen, "Time up for phishing with effective antiphishing research strategies," Int. J. Hum. Cap. Inf. Technol. Prof., 2015.

[33] A. Etemadzadeh, S. Seifi, and H. R. Far, "The Role of Questioning Technique in developing thinking Skills: The Ongoing Effect on Writing Skill," Procedia - Soc. Behav. Sci., 2013.

[34] E. A. Boa, A. Wattanatorn, and K. Tagong, "The development and validation of the Blended Socratic Method of Teaching (BSMT): An instructional model to enhance critical thinking skills of undergraduate business students," Kasetsart J. Soc. Sci., 2018.

[35] D. D. Samo, D. Darhim, and B. Kartasasmita, "Developing Contextual Mathematical Thinking Learning Model to Enhance Higher-Order Thinking Ability for Middle School Students," Int. Educ. Stud., 2017.

[36] B. L. Gaskaree, H. Mashhady, and M. Dousti, "Using critical thinking activities as tools to integrate language skills," Sino-US English Teach., 2010.

[37] C. Folke, S. R. Carpenter, B. Walker, M. Scheffer, T. Chapin, and J. Rockström, "Resilience thinking: Integrating resilience, adaptability and transformability," Ecol. Soc., 2010.

[38] P. Bourdieu, "Distinction: A social critique of the judgement of taste," in Sociological Perspectives on Sport: The Games Outside the Games, 2015.

[39] R. D. Arnold and J. P. Wade, "A definition of systems thinking: A systems approach," in Procedia Computer Science, 2015.

[40] S. A. Vong and W. Kaewurai, "Instructional model development to enhance critical thinking and critical thinking teaching ability of trainee students at regional teaching training center in Takeo province, Cambodia," Kasetsart J. Soc. Sci., 2017.

[41] A. R. Zeradjanin, J. P. Grote, G. Polymeros, and K. J. J. Mayrhofer, "A Critical Review on Hydrogen Evolution Electrocatalysis: Re-exploring the Volcano-relationship," Electroanalysis. 2016.

[42] P. P. E. Elicor, "Critical Thinking and Community of Inquiry within Professional Organizations in the Developing World," J. Hum. Values, 2017.

[43] W. D'Anna and G. Cascini, "Supporting sustainable innovation through TRIZ system thinking," in Procedia Engineering, 2011.

[44] P. Wächter, “Thinking in systems - a primer," Env. Polit., 2011.

[45] C. Y. Piawa, "Building a test to assess creative and critical thinking simultaneously," in Procedia - Social and Behavioral Sciences, 2010.

[46] T. Plomp and N. Nieveen, "Educational Design Research: an Introduction," in Proceedings of the seminar conducted at the East China Normal University, Shanghai (PR China), November 23-26, 2007, 2009.

[47] R. Paul and L. \& F. for C. T. Elder, "The miniature guide to critical thinking: Concepts and tools," 27th Int. Conf. Crit. Think., p. 12, 2012.

[48] K. El Hassan and G. Madhum, "Validating the Watson Glaser Critical Thinking Appraisal," High. Educ., 2007.

[49] S. Basu et al., "Collaborative Problem-solving Using a Cloud-based Infrastructure to Support High School STEM Education," 2015.

[50] S. S. Bracken and J. E. Fischel, "Relationships Between Social Skills, Behavioral Problems, and School Readiness for Head Start Children," NHSA Dialog, 2007.

[51] M. Y. Gokhale, M. S. Farahani, and J. Bagheri, "Numerical modeling of creeping flow past a square cylinder using Finite Volume Method," J . Adv. Appl. Math. Mech .J., 2016. 
[52] B. G. Glaser, "Conceptualization: On Theory and Theorizing Using Grounded Theory," Int. J. Qual. Methods, 2002.

[53] J. Pa, W. Goodson, A. Bloch, A. C. King, K. Yaffe, and D. E. Barnes, "Effect of exercise and cognitive activity on self-reported sleep quality in community-dwelling older adults with cognitive complaints: A randomized controlled trial," J. Am. Geriatr. Soc., 2014.

[54] R. L. Skains et al., "Become Certified in the Paul-Elder Framework for Critical Thinking," Comput. Compos., 2016.

\section{BIOGRAPHY}

Buhaerah

Doctorate in the field of mathematics education expertise. Lecturer in the mathematics education study program, State Islamic Institute of Parepare. Phone number: 081343870045

Siri Dangnga

Professor in the field of education expertise. Lecturer in the Faculty of Teacher Training and Education, Muhammadiyah University of Parepare. Phone number: 08124257930 